\title{
Między wojenną historią a kobiecą perspektywą
}

\section{Between the war history and woman's perspective}

\author{
||Jagoda Budzik
}

\begin{abstract}
The article is a review of the book Kobiety i/a doświadczenie wojny. 19141945 i później ('Women and/towards the Experience of War. 1914-1945 and Afterwards'). The author analyzes general aspects of book's composition, main assumptions and goals, focusing on the problem of the exact definition of the term „woman's perspective” and its meaning in the light of war and post-war discourse.
\end{abstract}

Key words: woman's perspective, World War I, World War II, postmemory

Streszczenie: Artykuł jest recenzją książki Kobiety i/a doświadczenie wojny. 19141945 i później. Autorka analizuje w niej ogólne aspekty kompozycji książki, jej głównych założeń i celów, skupiając się na problemie możliwych definicji pojęcia „kobiecej perspektywy" i jego znaczenia w kontekście dyskursu wojennego i powojennego.

Słowa kluczowe: kobieca perspektywa, I wojna światowa, II wojna światowa, postpamięć

Tom Kobiety i/a doświadczenie wojny. 1914-1945 i później pod redakcją Małgorzaty Grzywacz i Małgorzaty Okupnik jest pokonferencyjnym zbiorem artykułów, wśród których znajdują się zarówno rozważania o charakterze stricte naukowym, jak i teksty o nieco bardziej popularyzatorskim zabarwieniu. W znacznej większości zostały one wygłoszone podczas sesji o takim samym jak antologia tytule, zorganizowanej w grudniu 2014 roku przez Instytut Kulturoznawstwa Uniwersytetu im. Adama Mickiewicza.

Tak sformułowany problem, sytuujący kobiety nie w ramach doświadczenia, ale $\mathrm{w}$ relacji do niego, wprowadza kilka niejednoznaczności. Pierwsza z nich wiąże się z pytaniem, o jakim dokładnie rodzaju zależności między kobietami a wojną mowa. We wprowadzeniu redaktorki deklarują, że chodzi tu o wydobycie kobiecej perspektywy doświadczenia wojennego i zgłębianie jej specyfiki. Już na samym początku cytują fragment wstępu do 
Wojna nie ma $w$ sobie nic $z$ kobiety Swietłany Aleksijewicz, jednego z fundamentalnych dla refleksji nad kobiecym doświadczeniem wojny tekstów. W przywoływanym fragmencie białoruska noblistka upomina się o prawo kobiet do współtworzenia narracji o wojnie i zwraca uwagę na specyfikę właściwego im spojrzenia:

Wszystko, co wiemy o wojnie, powiedział nam „męski głos”. Wszyscy tkwimy w niewoli „męskich” wyobrażeń i „męskich” doznań wojennych. „Męskich” słów. Kobiety milczą. (...) Milczą nawet te, które były na wojnie. Jeśli nagle zaczynają mówić, to opowiadają nie o swojej wojnie, ale o cudzej. Innej. (...) Kiedy mówią kobiety, nie ma albo prawie nie ma tego, o czym zwykle czytamy i słuchamy: jak jedni ludzie po bohatersku zabijali innych i zwyciężyli. Kobiety opowiadają inaczej i o czym innym. „Kobieca” wojna ma swoje własne barwy, zapachy, własne oświetlenie i przestrzeń uczuć. Własne słowa. Nie ma tam bohaterów i niesamowitych wyczynów, są po prostu ludzie, zajęci swoimi ludzkimi-nieludzkimi sprawami. I cierpią tam nie tylko ludzie, ale także ziemia, ptaki, drzewa. Wszyscy, którzy żyją razem z nami na tym świecie. Cierpią bez słów, a to jest jeszcze straszniejsze... (Aleksijewicz 2015, 9-10).

Chwilę później autorki wprowadzenia zauważają również, że choć tematyka wojenna na stałe i w ramach różnych dyskursów została wpisana do repertuaru podejmowanych tematów, „opis i analiza doświadczenia historycznego kobiet z tej perspektywy pozostaje jednak dezyderatem badawczym" (s. $9^{1}$ ). Oddawana przez nie do rąk czytelnika antologia stanowi zbiór tekstów mających w założeniu przynajmniej częściowo odwrócić tę tendencję, przywracając wojennym narracjom perspektywę kobiecą na wielu poziomach: nie tylko przez badanie indywidualnych herstorii, lecz także opisywanie zjawisk znacznie ogólniejszej natury, oddających zbiorowe doświadczenia kobiet w omawianych okresach, których odzwierciedlenia poszukuje się tu w tekstach biograficznych i historycznych, jak również w dziełach literackich oraz twórczości plastycznej i muzycznej.

Kolejną kryjącą się w tytule niejednoznacznością są wyznaczane ramy czasowe: „1914-1945 i później”. W pierwszej chwili można odnieść wrażenie, że owo „później” odnosi się do następnych wojen z drugiej połowy XX i początku XXI wieku, które również zyskują stopniowo miejsce w refleksji humanistycznej i otrzymują kolejne kulturowe reprezentacje. W istocie okres ujęty w formułę „później” wiąże się jednak wyłącznie z następstwami ewokowanych przez daty roczne dwóch wojen światowych, a zatem ze zjawiskami postpamięci i przenoszonej pokoleniowo traumy. Choć we wstępie redaktorki odwołują się do przyjętej przez niektórych historyków (głównie z obszaru niemieckojęzycznego) strategii postrzegania wojen pierwszej połowy XX wieku w kategoriach „drugiej wojny trzydziestoletniej” (s. 10), a zatem doświadczenia rozgrywającego się na przestrzeni jednego pokolenia, struktura książki zakłada klarowny podział na trzy zasadnicze obszary czasowe: I wojny światowej, II wojny światowej oraz najbardziej pojemnego

1 Numery stron pochodzących z recenzowanego tomu podaję bezpośrednio w nawiasie.

\section{Polonistyka. Innowacje}

Numer 3, 2016 
okresu „po wojnie”, które determinują układ tekstów według chronologii opisywanych $\mathrm{w}$ nich zjawisk. Taka segmentacja $\mathrm{w}$ pewnym sensie wydaje się oczywista, nie pomaga wszakże w zniuansowaniu podejmowanej problematyki. Dla przykładu: redaktorki książki sygnalizują we wstępie niepodważalną specyficzność i odrębność doświadczenia Zagłady (s. 11), nie zostaje ono jednak wyodrębnione w strukturze tomu.

Teksty wchodzące w skład wymienionych wyżej, determinowanych nie problemowo, a chronologicznie, całostek zostały poprzedzone przebiegającym kilkuetapowo wprowadzeniem. W części antycypującej zasadnicze rozważania, zatytułowanej Wiek XX a fenomen wojny, umieszczone zostały dwa teksty: Wojna, pokój - i ponadto Haralda Sauberta oraz Dwie wojny Anny Wolff-Powęskiej. Swoiste dopełnienie kontekstu, który mają one zarysować, stanowią artykuły Tomasza Schramma: Czym była pierwsza wojna światowa? (umieszczony już w części Pierwsza wojna światowa) oraz Wojna lat 1939-1945, poprzedzający grupę tekstów skupiających się wokół tegoż konfliktu. Tego rodzaju uogólniającego wprowadzenia pozbawiona jest natomiast część skupiająca teksty o doświadczeniu powojennym. Prowadzone przez troje autorów-historyków rozważania prezentują różne pojawiające się dotychczas w historiografii strategie namysłu nad zjawiskiem nowożytnych wojen - zarówno w kontekście wyznaczających ramy tematyczne tomu dwóch wojen światowych, jak i nad naturą wojny w ogóle.

Co jednak znamienne (i zastanawiające), wszyscy troje niemal całkowicie pomijają perspektywę kobiecą, charakter ich tekstów wydaje się zdeterminowany przez hegemoniczną narrację historyczną, pomijającą kobiety jako specyficzny podmiot historii. I choć, jak wskazuje, między innymi, Aleksandra Ubertowska, studia nad wojną w perspektywie kobiecej wciąż są zjawiskiem stosunkowo nowym ${ }^{2}$, to jednak od lat 70 . XX wieku, a zatem przybliżonego czasu swoich narodzin, nurt historiografii feministycznej zdążył odegrać już istotną rolę we współczesnej humanistyce, w szczególności zaś w refleksji nad doświadczeniem wojny. Tymczasem w artykułach tworzących wstępne, historyczne tło pojawia się - w tekście Seuberta (s. 17) - jedna zaledwie wzmianka, która wskazywałaby na odmienność kobiecego spojrzenia na wojnę i jego znaczenie dla ogólnego myślenia o zjawisku wojny. W ten sposób kreślone w pierwszych rozdziałach całego tomu i poszczególnych jego części historyczne tło działa paradoksalnie na rzecz podtrzymania status quo i nie wpisuje się $\mathrm{w}$ artykułowany we wstępie postulat wprowadzania do historii wojennego doświadczenia nowej perspektywy. Tej doszukiwać się można dopiero wśród tekstów zawartych w zasadniczej części rozważań, choć nie we wszystkich przyjęto ją z jednakowym natężeniem. Antologia zawiera bowiem zarówno artykuły stanowiące pogłębioną refleksję nad kobiecym doświadczeniem wojny oraz jego specyfiką (zapowiadaną we wstępie i sugerowaną poniekąd przez tytuł), jak i teksty, których autorki

Por. m.in. Ubertowska Aleksandra, 2014, Holokaust. Auto (tanato)grafie, Warszawa, s. 115. 
i autorzy eksponują przede wszystkim opowieści o wojennych lub powojennych losach, z jakimi przyszło się mierzyć ich bohaterkom, przyznając tym samym pierwszeństwo opisowi zakorzenionemu w dyskursie biograficznym (częstokroć w znaczeniu biografii artystycznej).

Druga ze wspomnianych wyżej grup reprezentowana jest w tomie dość obszernie - antologia Kobiety i/a doświadczenie wojny. 1914-1945 i później skupia wiele (nierzadko zapomnianych) historii, o których pamięć niewątpliwie należy przywracać. Na jej kartach przywoływane są wojenne losy, między innymi, Matyldy z Windisch-Graetzów Sapieżyny, Edyty Stein, bł. Natalii Tułasiewiczówny czy Izabelli Komornickiej, żony oficera Wojska Polskiego, oraz Ireny - niani, która wraz z Izabellą i dziećmi udaje się na zesłanie na Syberię. Teksty te prezentują przekrój ról zajmowanych przez kobiety w wojennych warunkach, przede wszystkim jednak opowiadają indywidualne historie doświadczania tych realiów. Książka prezentuje też postaci wielu - nierzadko zapomnianych lub niedocenianych - artystek. W tekstach poświęconych, między innymi, Jo Mihaly, Marii Hiszpańskiej-Neumann, Idzie Kamińskiej czy Krystynie Piotrowskiej autorzy i autorki kreślą ścieżki artystycznych biografii skrzyżowane lub w całości pokrywające się z doświadczeniem wojny, skupiając się jednakże głównie na roli wojennej lub powojennej traumy dla procesu twórczego bardziej niż na - właściwej bohaterkom tekstów - kobiecej perspektywie i jej konsekwencjach.

Przykład tego rodzaju podejścia może stanowić tekst Wiesławy Tomaszewskiej Strona kobiet. O kobiecych rozpoznaniach wojny w utworach literackich. Jego autorka zestawia ze sobą trzy teksty różne pod względem okresu powstania, szczegółowej tematyki i formy, jako jedyne kryterium takiego zestawienia podając fakt, że „ich autorkami są kobiety, którym dane było zmierzyć się z doświadczeniem wojny" (s. 60). Same rozważania nad tekstami siostry Marii Walerii, Zofii Kossak-Szczuckiej i Marii Pawlikowskiej-Jasnorzewskiej nie prowadzą Tomaszewskiej do żadnych bardziej szczegółowych ustaleń mogących wydobyć partykularne właściwości kobiecego doświadczenia wojny, a raczej wiodą $\mathrm{w}$ stronę próby sformułowania ogólnych prawd dotyczących wojennego pisarstwa, pomijającej zupełnie element kobiecej tożsamości (s. 72). Jedyny specyficzny związek kobiety z wojną (oczywiście poza faktem przeżycia zbrojnego konfliktu), który omawia autorka, to rozumiana metaforycznie wojna ze starością, każdorazowo przez kobietę przegrywana, o której pisała Pawlikowska-Jasnorzewska (s. 68).

Tymczasem pytaniem szczególnie istotnym $\mathrm{w}$ obliczu zagadnienia kobiecej perspektywy doświadczania wojny jest pytanie o to, co czyni to doświadczenie koniecznym do wyodrębnienia, oraz o to, którędy przebiegają linie wewnętrznych podziałów między konkretnymi typami kobiecych doświadczeń. Dzięki różnorodności dyscyplin, z których wywodzą się autorzy i autorki tomu, pytania te (a niekiedy i wstępne na nie odpowiedzi) umieszczone zostają na wielu poziomach, w ramach różnych kontekstów. 
Zasygnalizowane przez redaktorki we wstępie wyjątkowe dla rozważań nad kobiecą perspektywą wojenną znaczenie pisarstwa Swietłany Aleksijewicz zostało szczegółowo omówione przez Aleksandrę Zywert w tekście Śmierć i dziewczyna. „Wojna nie ma w sobie nic z kobiety” Swietłany Aleksijewicz. Autorka przeprowadza w nim skrupulatną analizę przyjmowanych przez Aleksijewicz w jej pierwszej książce strategii budowania opowieści o wojnie i umieszcza je na tle snutych przez bohaterki Aleksijewicz historii, je same czyniąc $\mathrm{w}$ ten sposób pełnoprawnymi konstruktorkami wojennej narracji.

Odniesienia do rozpoznań autorki Wojna nie ma $w$ sobie nic $z$ kobiety pojawiają się także w tekście Patrycji Tomczak Simone Weil jedzie na wojnę, jednym z najciekawszych - również w kontekście rozważań nad specyfiką kobiecego doświadczenia wojny i próbami jego definicji - artykułów zebranych w tomie. Już na samym początku autorka wskazuje na paradoks związany nierozerwalnie $\mathrm{z}$ binarnym podziałem na perspektywę męską i kobiecą, podważając obecne mimowolnie również u wielokrotnie wspominanej w tomie Aleksijewicz założenie o tym, że „kobieca wojna dlatego <jest straszliwsza niż męska>, że <mężczyźni chowają się za historią, za faktami, wojna ich jako działanie i konflikt idei, interesów, a kobiety wychodzą od uczucia. Umieją widzieć to, co dla mężczyzn jest zakryte>" (s. 200). W kontekście dychotomicznego podziału na to, co męskie, silne i łączone z aktywną przemocą, oraz to, co kobiece, delikatne i słabe, przywołuje szczególnie istotny - a nadal słabo obecny w analizach kobiecego doświadczenia wojny - aspekt kobiecego sprawstwa (który również w omawianym tomie nie został poddany odrębnej analizie). Tomczak silnie akcentuje zarazem wątpliwość tak przeprowadzanego rozróżnienia, wskazując na aporetyczny charakter ponowienia „przemocowego gestu wykluczenia” w imię walki z jego skutkami (s. 199). Opisując doświadczenia Simone Weil na froncie hiszpańskiej wojny domowej, przedstawione m.in. w Iliadzie czyli poemacie siły, autorka nieustannie poddaje w wątpliwość stosowane w opisie wojny kulturowe konstrukty, jednoznacznie kwalifikowane jako kobiece lub męskie, bohaterkę szkicu sytuując z dala od tego rodzaju uproszczonych rozróżnień.

Barbara Kaszowska-Wandor z kolei, omawiając wojenne wspomnienia Karoliny Lanckorońskiej i proponując inny niż dotychczas przyjęty sposób ich interpretacji, zwraca uwagę na dodatkowe, uszczegóławiające ustalenia, których należy dokonać, analizując kobiece narracje wojenne: „Dopiero (...) indywidualizując tego, kto pisze, możemy pytać o indywidualność jego zapisu i wreszcie (...) możemy dostrzec zróżnicowane funkcje, jakim podporządkowane były zapisy wojenne" (s. 190). Kaszowska-Wandor zwraca również uwagę na podkreślane przez samą bohaterkę jej tekstu dodatkowe (choć przy tym, zdaje się, fundamentalne) rozróżnienia konieczne do poczynienia w refleksji nad tym, co ogólnie nazywamy kobiecym doświadczeniem, obejmujące zarówno kwestie pochodzenia (np. Polki, Żydówki), 
jak i poziom możliwych do przyjęcia przez kobietę życiowych i społecznych ról (np. matki i nie-matki). Konstatację tę, która u Kaszowskiej-Wandor prowadzi do wnikliwej analizy retorycznej tekstów Lanckorońskiej, pośrednio łączyć można z tropem, którym podążają m.in. Elżbieta Wasyłyk (która w rozdziale Kobieta i wojna. Wizualny zapis dramatu wojny w twórczości Käthe Kollwitz częściowo stara się odtworzyć szczególną perspektywę kobiety-artystki) czy Jakub Królikowski, stawiający w tekście Sztuka kobiety narzędziem obrony? Muzyka Grażyny Bacewicz w czasie drugiej wojny światowej pytanie o rolę kobiety-kompozytorki i specyfikę kobiecego procesu twórczego i muzyki w realiach wojny.

Innym szczególnie istotnym - a w refleksji nad wojną wciąż pozostającym w sferze tabu - wątkiem podejmowanym na kartach tomu jest przemoc seksualna wobec kobiet, która w realiach wojennych była zjawiskiem powszechnym ${ }^{3}$. Choć odniesienia do tego problemu pojawiają się również w innych tekstach, to dwa ważne aspekty zjawiska szczególnie wnikliwie analizują Magdalena M. Baran (Wojna $z$ mojego domu - niemieckich kobiet widzenia wojny) i Beata Przymuszała (Przemoc seksualna wobec Żydówek ukrywajacych się po „aryjskiej” stronie). Autorki skupiają się, rzecz jasna, na fundamentalnie różniących się od siebie typach kobiecego doświadczenia wojny: podczas gdy pierwsza omawia - przy uwzględnieniu całej ich różnorodności - doświadczenie niemieckich mieszkanek wojennego Berlina, druga pod kątem obrazów przemocy seksualnej wobec Żydówek ukrywających się poza murami getta czyta teksty Idy Fink i Hanny Krall. Podczas gdy Magdalena M. Baran podejmuje kwestię złożoności doświadczania wojny przez niemieckie kobiety, przemoc seksualną umieszczając na pozycji jego nierzadko integralnej części, Beata Przymuszała podkreśla szczególny wymiar zjawiska w odniesieniu do kobiet żydowskich i silną na kilku poziomach, zwielokrotnioną traumę, którą powoduje gwałt w sytuacji ukrywania się po „drugiej stronie” . Druga autorka wskazuje też na wartość literatury jako jednej z możliwych form opowiadania o tym doświadczeniu. Opowiadania wciąż, nawet wiele lat po wojnie, obarczonego dodatkowym ciężarem.

Szerzej, głównie w kontekście kolejnych pokoleń, specyfikę powojennego opowiadania o traumatycznych doświadczeniach podejmują teksty zamykające tom - szczególnie dwa szkice, autorstwa Sylwii Karolak i Sylwii Chutnik. W pierwszym z nich, zatytułowanym Druga wojna światowa $w$ kobiecych narracjach postmemorialnych, autorka prezentuje utrwalone $\mathrm{w}$ literaturze polskiej mechanizmy przenoszenia traumy na powojenne generacje, jednocześnie wskazując i szczegółowo omawiając specyfikę kobiecego doświadczenia tego procesu, najsilniej uwidaczniającą się w relacji między matką i córką. W drugim tekście przestrzenią rozważań staje się obszar kultury popularnej jako medium postpamięci o kobiecym

3 Zob. Sexual Violence Against Jewish Women During the Holocaust, 2010, Hedgepeth M. S., Seidel G. S., (red), Waltham. 
doświadczeniu wojny. Chutnik analizuje zrealizowany przez Muzeum Powstania Warszawskiego projekt Morowe Panny, podkreślając obecne w nim elementy polityki historycznej oraz przyjęte przez jego twórców strategie konstruowania wizerunku powstanki, wskazując na dodatkowe konsekwencje łączenia obszarów pamięci o wojnie i partyzantce, tematyki doświadczenia kobiecego i popkultury. Autorka pokazuje, że tego rodzaju pamięć o kobiecym doświadczeniu wojny skazuje je na liczne przetworzenia.

Wielość prezentowanych tu opowieści o wojennych i powojennych losach kobiet nie pozostawia wątpliwości: każda kolejna z tych już znanych albo czekających dopiero na odkrycie herstorii, odpowiednio przeczytana, pozwala przedefiniować znane z hegemonicznej, historycznej narracji doświadczenie wojny i oferuje dodatkową, możliwą do przyjęcia perspektywę. Tom pod redakcją Małgorzaty Grzywacz i Małgorzaty Okupnik z całą pewnością odwołuje się do kwestii istotnych i wciąż - zwłaszcza na gruncie polskim - obecnych w powszechnej refleksji jedynie punktowo. Skupia głosy badaczy i badaczek, autorek i autorów wywodzących się z różnych dyscyplin i szkół metodologicznych, reprezentujących różne perspektywy i światopoglądy. A w ramach procesu opowiadania historii/herstorii wojennego doświadczenia na nowo, każe postawić wiele pytań, m. in. o różnice między strategią odtwarzania wojennych losów kobiet a refleksją nad szczególną, właściwą im perspektywą i specyfiką ich doświadczenia.

\section{O Autorce:}

Jagoda Budzik - hebraistka, teatrolożka, doktorantka na Wydziale Filologii Polskiej i Klasycznej Uniwersytetu im. Adama Mickiewicza. Laureatka „Diamentowego Grantu” 2014 za projekt „Erec szam - kraj tam. Strategie konstruowania obrazu Polski w literackich i pozaliterackich tekstach kultury o Zagładzie izraelskich autorów trzeciego pokolenia". Naukowo interesuje się literaturą hebrajską i kulturą izraelską, szczególnie w kontekście pamięci o Zagładzie. 